\title{
Entre a política e o prazer: ditadura, arte e boêmia através do filme Garota de Ipanema (Leon Hirszman, 1967)
}

\author{
Between politics and pleasure: dictatorship, art and bohemia throughout Leon Hirszman's \\ Garota de Ipanema (1967)
}

\section{Entre la política y el placer: dictadura, arte y bohemia a través del film Garota de Ipanema (Leon Hirszman, 1967)}

Carlos Eduardo Pinto de Pinto*

\begin{abstract}
Resumo: O artigo aborda, através da análise do filme Garota de Ipanema (Leon Hirszman, 1967) e de seu circuito social, as tensões entre política e prazer no cotidiano do Rio de Janeiro durante a ditadura militar. A releitura de uma canção da Bossa Nova através de um filme que pretendia acompanhar o cotidiano de uma menina de classe média em Ipanema é esperada como um rompimento com os pressupostos do cinema político seguidos até então por seu diretor, um dos expoentes do Cinema Novo brasileiro. Afinal, tanto a Bossa quanto Ipanema eram consideradas metonímias de uma boêmia despolitizada que não se conectava, aparentemente, com a proposta de intervenção da arte na sociedade, seguida pelos cinemanovistas. Ironicamente, o filme decepcionou a crítica, justamente por não ser um bom entretenimento, se propondo a compreender a inserção da protagonista no mundo, inclusive sua relação com a política sob uma ditadura. Desse modo, a análise possibilita pensar as conexões entre ditadura, arte e boêmia no filme e através dele.
\end{abstract}

Palavras-chave: Cinema; Ditadura militar brasileira; Política; Cinema Novo; Bossa Nova.

Abstract: The article discusses, through the analysis of Leon Hirszman's Garota de Ipanema (1967) and its social circuit, tensions between politics and pleasure on daily life at Rio de Janeiro during the military dictatorship. The reinterpretation of a Bossa Nova song on a movie that intended to follow the daily life of a middle-class girl from Ipanema is expected as a break with the assumptions on how to make political cinema followed so far by its director, one of the exponents of Brazilian Cinema Novo (New Cinema). After all, both Ipanema and Bossa Nova were considered representative of a depoliticized bohemia apparently not worried with art intervention in society, important to Cinema Novo's filmmakers. Ironically, the film disappointed critics exactly because it was not a good entertainment, for it aimed to understand the relations of the "girl from Ipanema" with the world, including her perception of politics under a dictatorship. Thus, the analysis aims the connections between dictatorship, art and bohemia both on and through the film.

Keywords: Cinema; Brazilian military dictatorship; Politics; Cinema Novo; Bossa Nova.

Resumen: El artículo aborda, a través del análisis del film Garota de Ipanema (Leon Hirszman, 1967) y de su circuito social, las tensiones entre política y placer en el cotidiano de Rio de Janeiro durante la dictadura militar. La relectura de una canción de Bossa Nova a través de un film que pretendía acompañar el cotidiano de una niña de clase media en Ipanema es esperada como una ruptura con los presupuestos del cine político seguidos hasta entonces por su director, uno de los exponentes del Cinema Novo brasilero. Efectivamente, tanto la Bossa Nova como Ipanema eran consideradas metonimias de una bohemia despolitizada que no se conectaba, aparentemente, con la propuesta de intervención del arte en la sociedad, seguida por los cinemanovistas. Irónicamente, el film decepcionó a la crítica justamente por no ser un buen entretenimiento, mientras se proponía comprender la inserción de la protagonista en el mundo, inclusive su relación con la política bajo una dictadura. De este modo, el análisis posibilita pensar las conexiones entre dictadura, arte y bohemia, en el film y a través del mismo.

Palabras clave: Cine; dictadura militar; Política; Cine Novo; Bossa Nova.

* Professor Adjunto do Departamento de História do Instituto de Filosofia e Ciências Humanas da Universidade do Estado do Rio de Janeiro (IFCH/UERJ) dados biográficos_biographic data 
Em 1967, Leon Hirszman, cineasta vinculado ao Cinema Novo brasileiro, lançou o filme Garota de Ipanema, com a proposta de desconstruir o mito criado em 1962 pela canção homônima de Tom Jobim e Vinicius de Moraes (SALEM, 1997, p. 177). O maior sucesso internacional da Bossa Nova, que versava sobre uma "menina que vem e que passa num doce balanço, caminho do mar", ajudara a consolidar o imaginário do Rio de Janeiro - e, mais especificamente, de Ipanema - como um lugar vocacionado ao prazer. A proposta de Hirszman era adicionar complexidade a esse universo, realizando uma ficção-documentário capaz de retratar a "República de Ipanema" - modo como o bairro era referido por um grupo de cronistas que ajudaria a delinear, no fim da década, o imaginário sobre o bairro (QUEIROZ, 2011). Embora incorporasse muitos dos adjetivos propalados sobre Ipanema pela Bossa Nova, em sua vertente mais lírica, desde o início da década - boêmia, saudável, marítima, bem-humorada -, em 1967, com o país vivendo sob uma ditadura militar, a "República" se mostrava mais debochada e irônica, sobretudo quando o assunto era política.

A ideia do filme foi encarada por parte da imprensa - como será demonstrado mais adiante - como um gesto de ruptura com o Cinema Novo, mesmo sem qualquer declaração do diretor que endossasse tal leitura. A partir da interpretação de algumas críticas, é possível perceber que a política preconizada pelo movimento foi considerada inapropriada ao prazer associado à "República" (numa leitura do bairro que eclipsava sua dimensão politizada, talvez por se ater em demasia à representação realizada pela Bossa Nova em canções como a que inspirara o filme).

Vale lembrar que, movimento cinematográfico de vanguarda dos anos 1960, o Cinema Novo era marcado por narrativas politizadas sobre o Nordeste do Brasil e as favelas cariocas. Segundo Wolney Vianna Malafaia (2008, p. 202), os cinemanovistas "apresentavam-se, ao mesmo tempo, como observadores entusiasmados do desenvolvimento econômico e críticos contundentes das contradições geradas por esse mesmo desenvolvimento". Fazia parte da efervescência cultural do início da década de 1960, constituída por produções de cunho nacional-popular que seriam combatidas a partir de 1964, com o golpe civil-militar que instituiu a ditadura no Brasil.

Importante perceber que a localização do movimento no Rio de Janeiro possibilitava a observação e vivência de um espaço privilegiado da política nacional - sobretudo no que se refere às manifestações populares desde a posse de Jango, em setembro de 1961, até o golpe. O perfil do governo nacional - segundo o qual "era preciso reformar as bases do sistema econômico e do regime político" (REIS, 2004, p. 35) - estava intimamente associado aos movimentos de esquerda que encamparam suas propostas de cunho nacionalista, anti-imperialista e estatista. Os cineastas envolvidos com o Cinema Novo - fossem apenas simpatizantes das esquerdas, ou vinculados a alguma organização, como a AP (Ação Popular), ligada à juventude católica, ou o PCB (Partido Comunista Brasileiro) - também o apoiaram.

Após o golpe civil-militar de 1964, seguindo o ideário político de esquerda que o balizou desde o fim dos anos 1950, e ainda mais afinado com propostas cinematográficas da América Latina e da Europa, o Cinema Novo incluiria em seu repertório obras de reflexão crítica a respeito do regime autoritário, como $O$ desafio (Paulo César Saraceni, 1965) e Terra em transe (Glauber Rocha, 1967). Isso não significa que todos os cineastas e seus filmes tenham sido impactados diretamente pelo golpe, mas sua repercussão entre o grupo não pode ser ignorada.

A partir do que foi exposto acima, a suposta ruptura de Hirszman soava também como um afastamento dos pressupostos do cinema político, que, no caso cinemanovista, se notabilizaria por filmes de oposição ao golpe e à ditadura. Contudo, segundo suas declarações, o diretor não tinha intenções de abandonar o Cinema Novo, desejando apenas aplicar o mesmo rigor crítico lançado sobre as áreas depauperadas do país à Zona Sul carioca, reduto da classe média alta e da boêmia. Em uma entrevista ao Jornal do Brasil, reproduzida por Helena Salem (1997, p. 171-172), afirmou: "Não será um filme simplesmente nos termos tradicionais de um cinema de ficção alienante. Procurarei documentar esse pequeno mundo que circunda a garota de Ipanema (...)". E, embora não tenha verbalizado, a análise de seu filme permite conjecturar que ele também acreditava que a "República de Ipanema" pudesse ser boêmia e politizada, simultaneamente.

Segundo a memória de Norma Pereira Rego, esposa de Leon Hirszman na época da realização do filme, a ideia inicial da obra teria sido sugerida por ela: "Ele fez [o filme] um pouco por minha causa, porque eu disse: vocês só pensam em Nordeste. Eu não sei nada de Nordeste. Se eu fosse fazer um filme, faria um filme sobre uma garota de Ipanema" (SALEM, 1997, p. 177). Ainda que pese a ausência de uma confirmação de Leon sobre esse dado, penso que a observação dela encontrasse eco em 1965, quando o filme começou a ser idealizado. Afinal, esse é o momento em que alguns 
cinemanovistas se mostravam mais sensíveis diante da (re)definição do Cinema Novo, sobretudo no que concernia a sua capacidade de intervir na sociedade e de levar o público à revolução política. Enfim, a revolução intimista, o "olhar para si", era um dos imperativos em meados da década, convivendo, ainda, com a vontade de fazer política através do cinema.

De algum modo, o filme era um esforço para pensar a si e a seus pares, em sua maioria conectados ao universo da Zona Sul carioca (mesmo que nascidos em outros países, cidades e regiões do Rio, os cinemanovistas, quando não moravam na Zona Sul, eram assíduos frequentadores de seus espaços de sociabilidade, sobretudo os bares). Deixando momentaneamente de lado a alteridade da carestia, a ideia era olhar para essa geração que fazia política nos filmes, nos livros, nos jornais -, mas também nas praias, nas festas, nos botequins. Tal proposta não agradou à crítica, que rechaçou o filme - conforme será abordado mais adiante - considerado uma obra ambígua, que nem se realizava como Cinema Novo nem como um filme leve, de "sol, areia e mar", tal como prometia suas ligações com a canção Garota de Ipanema.

Acompanhar o circuito social do filme, de sua pré-produção à recepção, permite refletir sobre a inserção do Cinema Novo no cotidiano da ditadura que se instalara há três anos no país. Trata-se de compreender a relação contrastante de Garota de Ipanema com filmes realizados um pouco antes do golpe de 1964, como Cinco vezes favela (coletivo, 1962), Vidas secas (Nelson Pereira dos Santos, 1963), Os fuzis (Ruy Guerra, 1964) e Deus e o diabo na Terra do Sol (Glauber Rocha, 1964). Sobretudo, os últimos três - alçados a ícones de uma produção cultural politizada, libertária e bem-sucedida esteticamente, exibida e indicada a premiações nas edições de 1964 do Festival de Cannes (Vidas secas e Deus e o diabo) e de Berlim (Os fuzis). Ainda, convém notar a relação antitética com obras abertamente críticas ao golpe, uma tendência que se fortaleceria ao final da década (sobretudo a partir de dezembro 1968, após o AI-5), mas que já contava com alguns exemplos pioneiros no momento da estreia de Garota de Ipanema. É o caso de O desafio (Paulo César Saraceni, 1965), considerado o primeiro filme brasileiro a tematizar o golpe (CAMPO, 2011), e Terra em transe (Glauber Rocha, 1967), obra paradigmática na reflexão sobre governos autoritários na América Latina, lançado apenas sete meses antes do filme de Hirszman.

Além do circuito social da obra, o artigo analisa também a sua diegese (o enredo) e narrativa (o modo como a diegese é contada através dos recursos técnicos e estéticos), focando as experiências de sua protagonista, o que abre espaço para refletir sobre o que era ser uma "garota de Ipanema" após o golpe de 1964. Esta é uma distinção flagrante frente à "garota" da canção, criada em 1962, num país em meio a uma grave crise política, mas ainda democrático. A garota de 1967, mesmo que não engajada, precisava se posicionar diante dos movimentos contestatórios na política e nas artes, diferente de sua semelhante, que apenas passeava, graciosa, em direção ao mar. É através da caracterização dela, embora não somente, que o filme consegue construir um ponto de vista diante da ditadura. Longe de corroborar a leitura dos críticos, no sentido de que o filme se afastaria dos pressupostos do cinema político, a análise fílmica empreendida aqui possibilita pensar o modo como o filme tenciona temas relacionados à micro e à macropolítica, conceitos pensados a partir de Deleuze e Guattari (1996).

\section{Olha que coisa mais linda: a pré-produção}

Era com um tom leve e descontraído, como o de um amigo que chama a atenção do outro sobre uma menina que passeia pela praia, mote da canção de 1962, que o filme Garota de Ipanema seria esperado pelo público. Porém, realizado cinco anos após o surgimento da música, o filme - e, por conseguinte, o público - encontrava uma garota e uma Ipanema um pouco mudadas. A obra era, de fato, um desdobramento da canção, mas não uma tradução literal desta, apesar de homônimas. Aliás, batizar uma obra com o nome de outra, já tão reconhecida, trazia vantagens e desvantagens. Por um lado, a canção já funcionava como apelo ao grande público, o que foi reforçado pela participação de Vinicius de Moraes na campanha de lançamento; ${ }^{1}$ por outro, a expectativa por ver o universo que até então era ouvido, abria espaço para uma decepção. Conforme será abordado mais adiante, há indícios de que Leon Hirszman estivesse ciente do terreno delicado em que pisava, pois, como estratégia para evitar comparações em demasia, descrevia o filme

\footnotetext{
Vale notar as semelhanças entre a protagonista do filme e aquela de Pobre menina rica, musical de Vinicius de Moraes e Carlos Lyra, que estreara em 1963, que também versava sobre uma moça, pertencente a uma família endinheirada, que percebe a inutilidade do dinheiro na busca da felicidade. Desse modo, a participação do poeta e compositor na divulgação do filme, além de conectálo com a canção de 1962, também poderia prenunciar o universo diegético do filme.
} 
como uma desmitificação da "garota" da canção, que teria apenas servido de inspiração.

Esse era o terceiro filme do diretor carioca, nascido em 1937 e que cresceu no subúrbio, entre os bairros de Vila Isabel, Lins de Vasconcelos e Tijuca (SALEM, 1997). Hirszman iniciou a Escola Nacional de Engenharia, que abandonaria para se dedicar ao cinema. Foi fundador da Federação de Cineclubes do Rio de Janeiro, sediada no MAM (Museu de Arte Moderna), na época localizado no prédio da ABI (Associação Brasileira de Imprensa). Era ligado ao Teatro de Arena, tendo contato estreito com Augusto Boal e Oduvaldo Viana Filho. ${ }^{2} \mathrm{O}$ seu primeiro envolvimento com cinema ocorreu como assistente de direção em Juventude sem amanhã (Elzevir Pereira da Silva e João Cezar Galvão, 1958). É também um dos fundadores do CPC (Centro Popular de Cultura) da UNE (União Nacional dos Estudantes), no Rio, pelo qual realizou Pedreira de São Diogo, seu primeiro filme, um dos cinco curtasmetragens produzidos para compor Cinco vezes favela (produção do CPC da UNE, 1962).

O CPC tinha por objetivo "fazer a ligação entre o artista consciente e o povo", encarando a cultura como um "instrumento revolucionário" (SIMONARD, 2006, p. 85), seguindo o ideário nacional-popular que equiparava "nacionalidade" a "homens simples" - propalado pelo ISEB (Instituto Superior de Estudos Brasileiros) desde a década anterior (RIDENTI, 2000). Foi um dos mais eficientes espaços de socialização dos cinemanovistas no início do movimento, embora alguns cineastas nunca tenham tomado parte em suas atividades e outros tenham se afastado ainda no início da década de 1960. Para Pedro Simonard, os estranhamentos se deram por questão de ritmo: para o Cinema Novo, havia a "busca de uma forma nova para um homem novo", enquanto para o CPC, "a forma era secundária; o conteúdo é que tinha que ser novo" (SIMONARD, 2006, p. 87).

Talvez pelo que foi exposto acima, o primeiro longa-metragem de ficção de Leon, A falecida (1965), uma adaptação de Nelson Rodrigues ambientada na Zona Norte do Rio, tenha sofrido ataques da crítica identificada com o CPC, por se preocupar demais com a estética e menos com o conteúdo politizado. Nesse mesmo ano, sob o impacto do golpe de 1964, o diretor refugiou-se no Chile, voltando no ano seguinte para criar, com Marcos Farias, a produtora Saga Filmes, através da qual realizaria Garota de Ipanema.

\footnotetext{
2 Ambos expoentes do teatro político no Brasil.
}

A produção foi cara para os padrões do Cinema Novo - aliás, o primeiro filme a cores do movimento - o que ajudou a criar a impressão de um afastamento do slogan "uma câmera na mão e uma ideia na cabeça". Esse lema, por sua capacidade sintética, resumia as propostas do grupo, afirmando "a vocação crítica, política e realista do novo cinema brasileiro, um engajamento que também impunha uma busca de originalidade formal" (FIGUEIRÔA, 2004, p. 31). Vale, contudo, enfatizar que a ideia de um cinema realizado com poucos recursos, abordando temáticas politizadas e criando uma estética de vanguarda são balizas que ajudam a definir o movimento, mas não devem criar a impressão de uniformidade. O alcance e importância de cada uma dessas variáveis eram modulados de acordo com a opinião de diretores, críticos, jornalistas e teóricos em constantes reelaborações e disputas sobre o que seria o Cinema Novo. Considero fundamental levar em conta tal dinamismo, de modo a se perceber que o debate suscitado por um suposto afastamento de Hirszman a partir de Garota de Ipanema não surgia como fator desestabilizador de um movimento cinematográfico bem consolidado, mas como uma entre as muitas tensões que o constituíam.

A ideia de uma ruptura com o Cinema Novo nunca foi confirmada pelo diretor, ou anunciada na divulgação do filme, mas adveio da interpretação da crítica, que parecia não conceber uma abordagem cinemanovista de uma "garota de Ipanema" - esta, sim, a proposta apresentada pelos paratextos. Ainda em 1965, quando começava a esboçar o argumento do filme, Leon já declarava que não faria "um cinema de ficção alienante", mas que desejava documentar a vida da garota de Ipanema, "utilizando para isso a realidade, isto é, usando Vinicius de Moraes como Vinicius [...] e assim por diante" (SALEM, 1997, p. 172). Já às vésperas da estreia, na Folha de São Paulo (GAROTA de IPANEMA CHEGARÁ..., 1967), ${ }^{3}$ Vinicius de Moraes e Márcia Rodrigues (a atriz escolhida para protagonizar o filme), apresentavam a história como algo entre "leve e dramática". Vinícius acreditava no sucesso do filme, por conter "músicas, muito sol, areia e mar", arrematando com uma observação de Tom Jobim, segundo quem este era o "primeiro filme brasileiro que não tem terra". Márcia, por sua vez, concordava quando Vinicius dizia que "o filme é uma

\footnotetext{
3 Os textos de jornal usados aqui foram acessados através de recortes disponibilizados pela Cinemateca Brasileira, sem referências às páginas. CINEMATECA BRASILEIRA (Org.). Coleção de recortes de jornais e revistas sobre filmes brasileiros, 1958-1973. 44 recortes. Localizador P.29.
} 
declaração de amor ao Rio". Mas o poeta e compositor avisava logo que não se tratava de "uma historinha, tipo americana, tudo quadradinho. Há cortes e trechos irreais".

Esse tipo de matéria serve a preparar o espaço de comunicação (ODIN, 2011) do filme, como se preparasse o terreno para sua recepção (função também cumprida por cartazes e trailers). Há uma tentativa de direcionamento da leitura a ser efetivada pela crítica e pelo público, que são, no entanto, autônomos, podendo segui-los ou não. No caso de Garota de Ipanema é fácil perceber como as afirmações são ambíguas: ao mesmo tempo em que se confirma o clima da letra da canção de 1962 - "sol, areia e mar" - se avisa sobre a presença de "cortes e trechos irreais". Seja lá o que o uso do adjetivo "irreal" pudesse significar precisamente, soava como uma negação do clima edênico sugerido pela tríade apontada antes. A situação era ainda mais complexa na medida em que Leon incluiu no filme uma quantidade imensa de participações especiais de celebridades (de inúmeras áreas), todos residentes ou frequentadores do bairro. Acenava, desse modo, com a promessa de retratar a "verdadeira" Ipanema de 1967.

Nesse sentido, a Revista Visão (UM AMOR de GAROTA..., 1967), em matéria sobre o lançamento do filme, apontou para a presença de todos do "Grand Rio". É reforçado o fato de a obra ser a primeira experiência em cores do Cinema Novo, com a intenção de mostrar ao Brasil onde ele "não é" subdesenvolvido: "Nossa juventude inteligente, a glória do surf nas águas do Arpoador, a música de Tom Jobim, o poeta Vinicius cantando em sua sala, o violão de Baden Powell, o salão do Municipal, (...) a mulher (que o Sol fez morena (...)". A matéria continuava, afirmando que a presença de tantas personalidades daria ao filme um "tempero de documentário alegre, inédito entre nós". Finalmente, o "espectador mal humorado [sic] sempre reclamando que o cinema brasileiro só mostra favelado e cangaceiro terá de mudar a agressão por um certo tempo".

Carlos Leonam, jornalista, morador de Ipanema - parte, portanto, do "Grand Rio" - foi um dos que atuou como figuração de luxo. Em 1967, publicou uma matéria no Jornal do Brasil anunciando a produção do filme e identificando todas as participações especiais - ou quase todas, "em um elenco de três milhões, quinhentas e trinta e cinco mil, cento e duas pessoas, fora uma cachorra". Mais importante que a identificação dessas participações, contudo, é a forma como ele apresenta o filme. Em tom de humor, define as peculiaridades da obra. Primeiro, certamente daria dinheiro, devido à ausência de qualquer "pretensão de ganhar prêmios em festivais". Segundo, inovava na temática, sendo a primeira "tentativa de um filme do Cinema Novo sem Nordeste ou favelas". ${ }^{4}$ Ao contrário, seria colorido, "alegre como a alienação da burguesia reacionária” (LEONAM, 1998, p. 211).

Esta última afirmação de Leonam remete à ideia de ruptura com o Cinema Novo. A adesão à alienação burguesa é bem vista, comemorada, e prepara os leitores para a recepção de um filme despolitizado. Enfim, em seu espaço de comunicação, a obra não conseguiu se desvencilhar totalmente do mote que lhe deu origem. Afinal, em 1967, a "moça do corpo dourado do Sol de Ipanema" era capaz de fazer qualquer pessoa minimamente informada associar sua figura a uma leitura do Rio que privilegiava as praias, a juventude, a descontração e - por proximidade - a alienação.

\section{A outra garota de Ipanema: a produção e seu resultado}

A produção do filme ficou a cargo da empresa recém-criada por Leon e Marcos Farias, a Saga Filmes, que investiu pesado na criação de um filme colorido, ainda uma ousadia para o cinema brasileiro naquele momento. Para dar conta do desafio, foi contratado o já experimente fotógrafo argentino Ricardo Aronovich (ADES; KAUFMAN, 2007). Apesar da intenção de "desmitificar" a canção Garota de Ipanema, Vinicius de Moraes, um de seus compositores, participou da idealização do filme, escrevendo o argumento com Leon Hirszman, que contou também com uma participação de Glauber Rocha. O roteiro seria de Hirszman e Eduardo Coutinho, acrescido de muito improviso ao longo das gravações (SALEM, 1997). Márcia Rodrigues, a protagonista, foi selecionada através de um concurso de que participaram pouco mais de uma centena de atrizes iniciantes.

A diegese de Garota de Ipanema acompanha o processo de amadurecimento de Márcia, 17 anos, pertencente à classe média de Ipanema. $\mathrm{O}$ filme se estrutura em três etapas: no princípio, apresenta a vida agitada da protagonista, até o rompimento com

\footnotetext{
${ }^{4}$ Garota de Ipanema não é, efetivamente, o primeiro filme urbano "sem favelas" do movimento, sendo antecedido por Os cafajestes (Ruy Guerra, 1962) e $O$ desafio (Paulo César Saraceni, 1965). Contudo, a memória do Cinema Novo como um movimento focado nos espaços representativos da exclusão social é tão forte que parece eclipsar tais obras.
} 
o namorado surfista; em seguida, acompanha um malsucedido romance pigmaleônico com um fotógrafo mais velho; na reta final, segue a sua "fossa", até uma sugerida iniciação sexual durante um baile carnavalesco no Theatro Municipal do Rio. A praia e o apartamento dos pais são os espaços de socialização mais usados pela personagem, em rodinhas de conversa nas areias ou em festas embaladas pela Bossa Nova.

O trecho que passo a analisar ocorre após o rompimento com o namorado surfista, ainda no início da narrativa. Trata-se da primeira de muitas reuniões típicas da fase inicial da Bossa Nova a serem apresentadas ao longo do filme: uma espécie de sarau em estilo "banquinho e violão", tendo Nara Leão e Chico Buarque entre os convidados do evento. Ela é carioca (Tom Jobim/Vinicius de Moraes) é executada pelo Tamba Quarteto. Enquanto se ouve "Ela é carioca, ela é carioca/ Basta o jeitinho dela andar...", se pode observar a decoração, que exibe uma mistura equilibrada entre peças clássicas e modernistas, tanto nos móveis, como nas obras de arte.

Pedro Paulo (Arduino Colasanti), o ex-namorado de Márcia, chega à festa e logo entabula uma discussão discreta na varanda. Enquanto isso, Nara Leão, reclinada em uma cadeira de balanço e com olhar fixo na câmera, canta Lamento no Morro (Tom Jobim/ Vinicius de Moraes), acompanhada pelo Quarteto e cercada pelos amigos de Márcia: "Não posso esquecer o teu olhar longe dos olhos meus/ Ah, o meu viver é de esperar pra te dizer adeus". Ao fim de sua "apresentação", a cantora fala com Chico, se referindo a uma moça: "Olha aí, está perguntando se é nova...". Ato contínuo, olha para a menina e diz com tom professoral: "Tem quase dez anos. É do Orfeu da Conceição". ${ }^{5}$

Em seguida, Márcia chama o ex-namorado para ver Chico Buarque com violão em punho, cantando Um chorinho, de sua autoria. Ele está sentado em um sofá, à frente de uma tela modernista de grandes dimensões. Márcia se encontra a seus pés - literal e metaforicamente - e Nara, diante dele. Pedro Paulo observa a rendição de Márcia ao cantor, cena que é seguida de um flashback em tom de sépia, com imagens remetendo ao namoro desfeito. Vale notar que tal sequência é acompanhada pelo chorinho, que começa com os seguintes versos: "Ai o meu amor, a sua dor, a nossa vida/ Já não cabem mais na batida do meu cavaquinho". Interessante notar que todas as

\footnotetext{
5 Peça musical de Vinícius de Moraes, com trilha sonora composta por ele mesmo e Tom Jobim. Trata-se de adaptação do mito grego de Eurídice e Orfeu transposto para as favelas cariocas. Inspirou o filme Orfeu Negro (Orphée Noir, Brasil/França, Marcel Camus, 1959).
}

letras sublinham a situação diegética, contrastando a "carioquice" de uma garota, que bem poderia ser Márcia, com dois lamentos de homens que sofrem pela ausência de suas amadas, certamente papel que Pedro Paulo desempenha ali.

A trilha é um dado sensível do filme, certamente devido a sua contiguidade genética com a Bossa Nova. A maneira como as canções são usadas, contudo, permite refletir sobre o descompasso de Márcia - e do filme - com o cenário musical brasileiro em 1967. Nesse momento, os Festivais da Canção ${ }^{6}$, fenômeno de massa fomentado pela $\mathrm{TV}$, haviam criado uma arena para o confronto de estilos e ideologias, com destaque para a canção de protesto, a MPB e o Tropicalismo. Também na TV, mas fora dos Festivais, estava a Jovem Guarda (NEDER, 2012). A própria Bossa tinha passado por uma clivagem, já no início da década de 1960 , quando alguns de seus componentes começaram a compor o que ficou genericamente conhecido como "canções de protesto" (NAPOLITANO, 2007, p. 72). Tratava-se de uma aproximação dos ideais do CPC, que resultaria em temas "de conteúdo sociopolítico como pobreza, habitação, terra, reforma agrária, desemprego, subemprego" (CALDAS, 2005, p. 94). Não é essa vertente a privilegiada aqui, mas aquela conectada com o lirismo. Vale notar, contudo, que não se tratava de uma divisão estanque e sem diálogos os mesmos compositores que se notabilizaram por canções de protesto poderiam fazer canções líricas e vice-versa. O "descompasso" a que me referi no início do parágrafo não é uma condenação ao uso de canções líricas na trilha, mas uma ênfase no eclipse das canções de protesto.

O caso de Nara Leão é bastante significativo: uma das musas da Bossa Nova em seu princípio, foi também um dos artistas que se engajou em sua vertente mais politizada (CALDAS, 2005, p. 124), que marcou, por exemplo, o seu LP de estreia, Nara (1964) e sua participação no espetáculo Opinião (1965) - considerado a primeira manifestação artística de oposição ao regime militar (RIDENTI, 2003, p. 124; SUKMAN, 2011, p. 61-2). Em 1967, Nara ainda estava conectada com esse universo, tendo se aproximado de outros compositores jovens, como Chico Buarque, ligado à nascente MPB (com quem apresentara, entre 1966 e 1967, o programa da TV Record Para ver a banda passar). No filme, contracenando com Chico,

\footnotetext{
O primeiro aconteceu em 1965, em São Paulo, promovido pela TV Excelsior. Em 1966, haveria o primeiro do Rio e o segundo de São Paulo. Em 1967, o Terceiro Festival da MPB, organizado pela TV Record.
} 
ela apenas aparece em rodinhas de voz e violão, executando canções idílicas, sem qualquer menção à dimensão mais politizada de suas carreiras. Talvez por se ater excessivamente ao "clima" sugerido pela canção que deu origem a seu filme, Leon acabou por eclipsar uma série de manifestações artísticas ligadas (não somente, mas de modo proeminente) à oposição à ditadura (NAPOLITANO, 2014, p. 105-6; RIDENTI, 2003, p. 124).

Márcia não assiste à TV, nem participa dos Festivais. Fora a Bossa, somente canções em inglês e o $i \hat{e}-i \hat{e}-i \hat{e}$ de Roberto Carlos, executados nas festas, funcionam como indícios da variedade de seu gosto musical. Contudo, é bom reforçar que esses últimos casos não estão explicitamente vinculados à singularidade da personagem, já que poderiam fazer parte dos ambientes frequentados por ela, mas não necessariamente de suas preferências. Fato é que, em casa, Márcia só ouve canções líricas bossanovistas, ou estilisticamente próximas.

No dia seguinte à discussão com Pedro Paulo na festa em seu apartamento, Márcia é abordada por um cafajeste que a persegue pelas ruas de Ipanema. Um corte indica que a garota - depois do contratempo - foi se encontrar com o primo Zeca (José Carlos Marques), que acabou de voltar de Paris. Durante o diálogo, que serve a colocar os dois a par de suas vidas, Zeca fala de Paris, de uma exposição do Picasso, de um filme do Godard, de uma conferência de Sartre e de uma greve geral. Márcia graceja em tom descontraído, mas irônico, intercalando sua fala com risadas discretas: "Nós também temos novidades. Olha... nomeação de dez novos generais, o Pelé teve uma filha, o território do Amapá vai ser estado...”.

É a primeira vez que a personagem aborda um tema político, ainda que de maneira descompromissada. Evidente que a referência aos generais serve para marcar a monotonia do Rio frente a Paris e sua vida excitante, plena de modernismo, existencialismo, protestos e Nouvelle Vague, mas é também uma ancoragem do filme no contexto político do país. Frágil, por certo, mas coerente com a primeira parte da narrativa, marcada pela vivência hedonista de uma menina de 17 anos, moradora de um dos bairros mais elitistas do Rio na década de 1960. Há pouquíssimos traços que remetem a conflitos sociais nessa Ipanema "onde o eco da luta diária dos homens (...) vai se perder no mar”, para citar um trecho do diário que a protagonista lê no início do filme. São raras as presenças de figurantes que possam representar trabalhadores pobres e/ou negros: alguns pescadores no Jardim de Alah, umbandistas numa noite de Réveillon, um vendedor de mate na praia. Frente a isso, a presença de brancos aparentemente bem-nascidos ganha força como ponto focal da trama, o que é ainda mais relevante por se tratar de um filme cinemanovista.

Como já observei ao abordar a trilha sonora, a narrativa se prende, nesta primeira parte, a sua protagonista, cujas angústias estão vinculadas ao plano privado, circunscrita à micropolítica, mas isso não significa que esteja completamente alheia à macropolítica. Segundo Deleuze e Guattari (1996), esta faz referência aos aspectos instituídos da vida pública e, nesse sentido, está relacionada à política institucional. A micropolítica, por sua vez, se associa aos movimentos instituintes, a processos que poderão ou não se consolidar na macropolítica. Não raro, algumas questões perpassam ambas as esferas, o que parece ser o caso, aqui, da ditadura.

A segunda etapa da narrativa começa quando Márcia se apaixona por um homem cujo nome nunca é revelado, sendo referido aqui como o Fotógrafo. Como mencionei, é uma relação pigmaleônica, em que o homem tenta fazer com que Márcia conheça o mundo e a si mesma, e deseja iniciá-la sexualmente - sendo relativamente bem-sucedido apenas nos primeiros propósitos. Apesar de ser um romance, a tensão perpassa todo o relacionamento, já que Márcia desconfia desde cedo que ele seja casado (o que logo se confirma) e fica apreensiva diante da possibilidade de ter sua primeira relação sexual. $\mathrm{O}$ contato com o "mundo", apesar de perpassado pelo humor, também ganha contornos angustiantes.

Uma sequência típica desse processo apresenta elevado interesse aqui, por abordar, de forma cômica, a relação de Márcia com a política. O Fotógrafo propõe a realização de uma sessão de fotos em estúdio, em que Márcia poderia experimentar "mil disfarces". As imagens são apresentadas através de uma montagem ágil, que apresenta takes de Márcia fantasiada, acompanhados de comentários em off do Fotógrafo, com a execução de Garota de Ipanema em versão instrumental, mixada a ruídos que tendem a gerar efeitos cômicos.

Márcia posa mimetizando diversos papéis sociais, tais como noiva, dona de casa, prostituta e feminista - ou lésbica, já que as roupas típicas do vestuário masculino, os cabelos curtos e os gestos contidos, acompanhados do comentário do Fotógrafo, que diz

\footnotetext{
7 Enquanto as imagens de Márcia são exibidas, apenas ouvimos a voz do Fotógrafo explicando cada situação.
} 


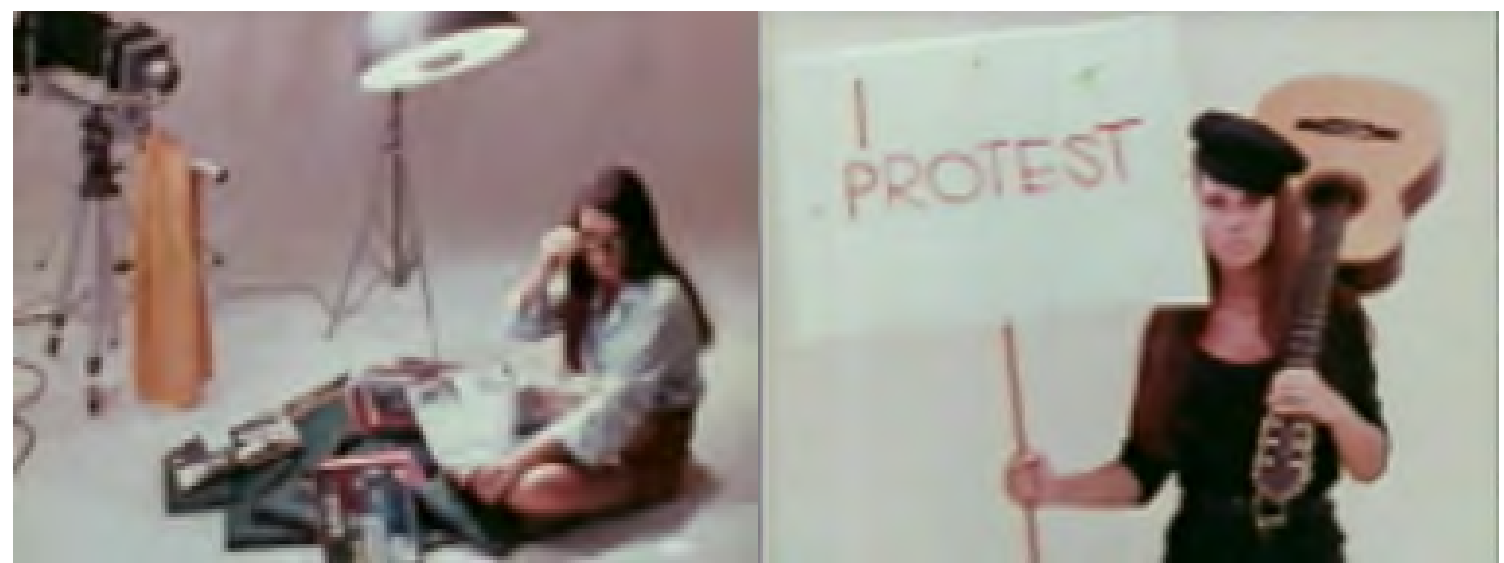

Figura 1. Márcia como "intelectual teórica".

Figura 2. Márcia como "intelectual prática". Fonte: Frames captados pelo autor a partir de uma cópia do filme em DVD.

achar um exagero, permitem essa dupla interpretação, dentro da chave caricatural proposta pela sequência. Instigante é a distinção realizada entre intelectual teórica e prática, representadas conforme se pode ver nos frames reproduzidos acima (Figuras 1 e 2).

Na primeira, Márcia ajeita os óculos, em meio a um pequeno monte de livros espalhados pelo chão. A situação em si, acrescida da câmera fotográfica aparente e do holofote, remetem à artificialidade dessa postura. Não menos caricata, mas contendo mais ênfase na encenação, a intelectual prática usa roupas pretas e boina, indício de uma referência aos existencialistas franceses e seus pretensos modelos alternativos de vida e política; carrega um cartaz de protesto escrito em inglês, remetendo aos diversos movimentos civis norte-americanos ao longo dos anos 1960 e, o que se conecta com a trilha sonora do filme, um violão apoiado sobre um dos ombros.

Embora não seja privilégio nacional, é imperativo pensar na importância do violão para as canções de protesto brasileiras, sem esquecer a "Passeata contra a guitarra elétrica", ocorrida em meados de 1967, em São Paulo, que tentava defender a nascente MPB, representada pelo violão, da invasão da música estrangeira. Não encontrei indícios de que Leon tenha se inspirado no episódio, mas a sua ocorrência durante as filmagens da obra pode ao menos dar a certeza de que tais debates poderiam ter sensibilizado o diretor na hora de criar esse take. A partir dessa suposição, fica ainda mais flagrante a opção de inserir, na trilha, apenas a versão mais lírica da Bossa Nova, eclipsando as diversas opções de música de protesto (tenuemente representadas por essa fotografia).

A continuação da sessão de fotos apresenta outras representações férteis para o que discuto aqui. $\mathrm{Na}$ sequência, Márcia surge como militar (Fig. 3), "defensora da ordem estabelecida", nas palavras do Fotógrafo; guerrilheira (Fig. 4), "inimiga de la ordem estabelecida" e mendiga (Fig. 5), "vítima da ordem estabelecida". Essa espécie de tríptico coloca em contraste situações diretamente ligadas à macropolítica, com as quais Márcia precisaria se confrontar.

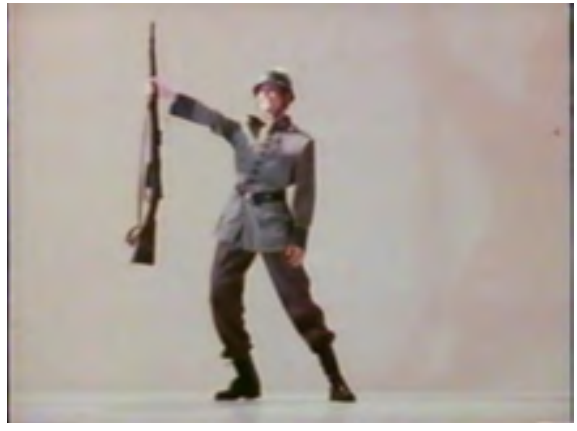

Figura 3. Márcia como militar, "defensora da ordem estabelecida".

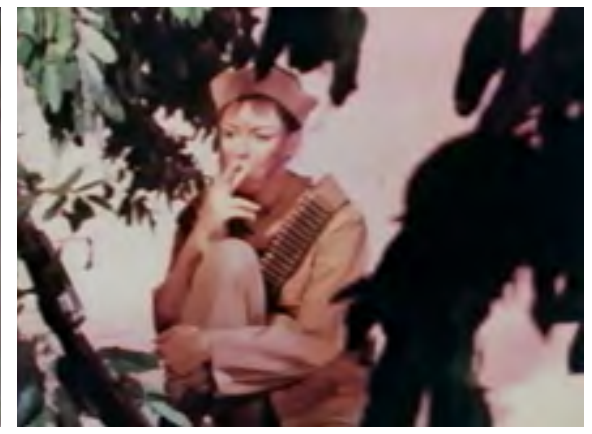

Figura 4. Márcia como guerrilheira, "inimiga de la ordem estabelecida".

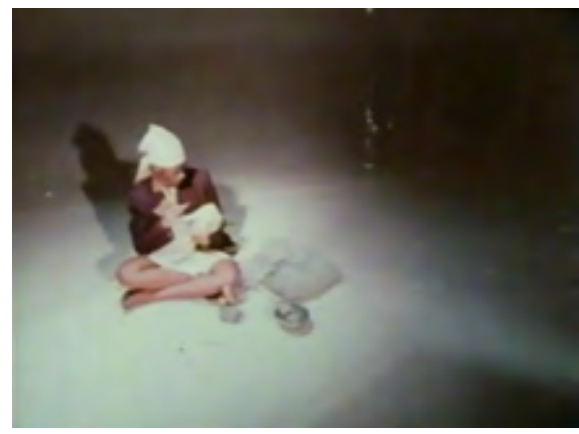

Figura 5. Márcia como mendiga, "vítima da ordem estabelecida".

Fonte: Frames captados pelo autor a partir de uma cópia do filme em DVD. 
O tom continua sendo cômico, com piadas sonoras realizadas pela trilha, que endossa o gestual caricato assumido pela atriz, mas, diferente das opções apresentadas até agora, não parece que esses sejam papéis de fato ao alcance da personagem. Ela poderia ser muitas outras coisas, mas não militar, guerrilheira (dada a sua autodeclarada ignorância política) ou mendiga (ainda que se possa imaginar um revés na situação financeira da família de classe média alta, ser mendiga não apareceria como uma escolha). Aqui, o que parece mesmo se dar é mais um contato tangencial do filme com o contexto sociopolítico do país.

Isto é reforçado quando Márcia se depara com algumas perguntas curtas do Fotógrafo, que tenta conhecê-la de modo mais aprofundado. Quando o assunto abordado é política, Márcia dá um sorriso tímido e diz: "Ah, eu não entendo nada disso! O pessoal lá na Faculdade me chama para fazer greve, passeata... Sabe que eu fui numa passeata ultimamente? Mas a polícia chegou lá, baixou o pau e no corre-corre eu levei um tombo (risos)". O tom descontraído da sessão de fotos é mantido aqui. A política, para a garota de Ipanema, é um tema obscuro, cujo perigo pode ser pressentido pela perseguição policial, mas não tão gravemente a ponto de a impedir de se indignar com o seu tombo. Ao contrário, o episódio é narrado com a leveza de uma anedota.

Em seguida, o jogo se inverte e é Márcia quem quer saber mais sobre seu interlocutor. Questionado sobre sua biografia, o Fotógrafo narra uma fábula pautada por encontros com piratas e cangaceiros, fugas em carros de boi e fragatas, encontros com um pai de santo e a Coluna Prestes. Ainda que não se trate, como no caso de Márcia, de uma sessão de fotos com mudança de figurino e de maquiagem, ele também explicita a encenação através de gestos miméticos caricaturais que beiram o ridículo, de tão mal realizados. Longe de remeter à falta de talento do ator, essa opção parece querer reforçar o tom de brincadeira descompromissada que a narrativa assume aqui, quando faz referências a temas políticos caros ao Cinema Novo. Mais que isso, aponta para o modo fabulizante de ver, definido por Roger Odin (2005, p. 29) como aquele que serve a retirar um ensinamento da narrativa. Não coincidentemente, este é, junto com o modo documentário - usado para obter informações sobre a realidade do mundo, também presente em Garota de Ipanema - um dos modos mais utilizados pelo Cinema Novo.

Mais adiante, em uma longa sequência - que é chamada, pelo Fotógrafo, de "A Grande Ascensão" -, ele assume postura mais séria, embora ainda caricata, misturando temas políticos, como a Guerra Fria, a metafísicos. Num momento em que a sequência ganha contornos mais românticos, ele se aproxima de Márcia, na iminência de um beijo, e sussurra: "Esquece a bomba, as guerras santas, o câncer, a luta de classes, a solidão, a mais-valia, o desencontro, a fome, o racismo e a imensa vaidade do Homem". Interessante que o mesmo personagem que apresenta o universo da política à garota de Ipanema, seja aquele que solicita que ela esqueça esses temas, na iminência de rolar pelas areias de uma praia não identificada. Se nas sequências realizadas no estúdio fotográfico o tom caricatural e satírico parece querer desqualificar a política, aqui ela simplesmente parece perder qualquer importância diante de um idílio. A sequência é concluída com a recusa de Márcia ao beijo e à relação sexual (que seria a sua primeira) com um homem casado. Na reta final do filme, Márcia enfrenta a tristeza pelo fim de seu romance e parece dar a volta por cima num baile de Carnaval, possivelmente quando ocorre sua primeira experiência sexual.

Nas sessões de fotografia, na biografia do Fotógrafo e na sequência da Grande Ascensão, analisadas acima, a política, um dos temas caros ao Cinema Novo, é tratado de forma superficial. Como demonstrei, isso ocorre também com outros temas, sempre tangenciados, mas nunca aprofundados. É o caso da pobreza e da exclusão social, representadas através de poucos trabalhadores negros que surgem discretamente nas tomadas na praia; da religião popular, através de uma roda de umbanda num Réveillon; e do carnaval, no encerramento do filme.

No caso da política, contudo, mais do que ausência de aprofundamento, parece haver um distanciamento que beira a ridicularização, marcadamente nas sequências em que temas políticos parecem ser alvo de sátiras. Isso é ainda agravado pelo fato de o personagem diretamente envolvido ser um fotógrafo, o que o conecta com o uso da câmera - como se o olhar do Cinema Novo, que ele mimetiza, fosse distinto do olhar do filme e objeto de deboche. Contudo, paratextos produzidos por Hirszman, como o abordado acima, em que afirma não ter a intenção de fazer uma "ficção alienante", indicam o desejo de realizar um filme cinemanovista (considerando-se a politização como um traço identitário do movimento e o oposto de uma "ficção alienante"). Cabe, então, tentar compreender, com os elementos abordados aqui, como ele ensaiou unir, numa mesma obra, elementos associados a um universo apolítico - a vertente lírica da Bossa Nova 
e sua representação de Ipanema em 1962 - com os pressupostos do cinema engajado politicamente em busca da "República de Ipanema", em 1967.

Essa tentativa de realizar uma representação atualizada de Ipanema se dava, conforme indicado no início do artigo, através do contato com textos de cronistas que construíram um imaginário social para o bairro, com o qual Leon e os outros cinemanovistas se identificavam. Logo, poderia dizer que a "desmitificação" a que o diretor se propunha seria, mais precisamente, uma "transmitificação" - a passagem de um mito a outro, da Ipanema bossanovista para a "República de Ipanema". Contudo, através de uma operação mais complexa, o filme acaba mobilizando outros olhares - como o modo fabulizante de ver, bastante associado ao Cinema Novo - e também outras escutas, já que a Bossa Nova mais lírica permaneceu como um dos acessos à garota e ao bairro.

No fim, tal caleidoscópio dificulta a apreensão de Márcia e de Ipanema como únicas. Por um lado, a proximidade da Bossa Nova marcada pelo lirismo e pela representação idílica da figura feminina e da cidade é lida como sinônimo de alienação pelos padrões cinemanovistas. Numa primeira visada, nada de estranho: o filme estaria reconstruindo uma personagem bossanovista "clássica" para lançar sobre ela a perspectiva crítica do Cinema Novo. Contudo, a personagem Márcia, com graus muito altos de angústia e de recato sexual, gera ruídos se "ouvida" como criatura da Bossa Nova. É possível conjecturar, portanto, que ela tivesse sido "resgatada" do universo bossanovista para ser transformada em uma personagem cinemanovista e cidadã da "República de Ipanema". Mesmo assim, restam alguns entraves: embora a angústia existencial pudesse ser um ponto a se levar em consideração para considerá-la uma legítima personagem do Cinema Novo - conforme defenderiam alguns críticos - o excesso de recato sexual e a propalada alienação impediam o encaixe tanto no Cinema Novo quanto na "República".

Ainda, a onipresença de espaços vinculados ao hedonismo, sobretudo a praia, em que a exclusão social surge discretamente e nunca é discutida, também funcionava como impedimento à representação cinemanovista. No entanto, antes disso, parece que o próprio Cinema Novo já não convencia a si mesmo, sendo tematizado pela narrativa como "outro" olhar - representado pelo Fotógrafo e pela sequência da "Grande ascensão". Ao fim, parece que Leon, ao supostamente aceitar o desafio de sua esposa na época - fazer um filme sobre um universo íntimo, facilmente reconhecido por ele e por seus pares - se viu enredado num emaranhado de representações contraditórias. Sem acreditar na dicotomia Cinema Novo versus Ipanema e Bossa Nova, ou política versus prazer, acabou por corroborar tais distâncias, conforme demonstro agora, a partir da amostragem de algumas críticas realizadas sobre o filme.

\section{Um filme ambíguo e a crítica decepcionada}

Garota de Ipanema estreou em dezembro de 1967, recebendo muitas avaliações negativas. Os críticos repetiram e reiteraram os paratextos divulgados em seu espaço de comunicação, indicando que haviam aceitado a ideia da diferenciação entre a "garota" do filme e da canção, mas não a percebiam na prática. Apesar disso, há indícios de que a produção tenha se pagado na bilheteria (SALEM, 1997), o que pode significar que, para o público, as relações com a canção original tenham funcionado como um chamariz eficiente.

O Jornal do Brasil organizou uma página com quatro críticas, sendo apenas três assinadas (às quais me atenho aqui). Todas elogiavam aspectos técnicos, sobretudo a fotografa, mas condenavam o tratamento dado à diegese. $\mathrm{O}$ uso da fotografia em cores - como já afirmei, uma novidade para o Cinema Novo - foi interpretado, de modo geral, como promessa de mais alegria, descontração e jovialidade. Tais elementos, no entanto, não eram sustentados pelo enredo, resultando em uma decepção.

Nesse sentido, Alberto Shatovsky ${ }^{8}$ (1967, p. 8) enfatizou o malogro do cinema brasileiro em ensaiar "a cor, a praia, a festiva existência burguesa". Afinal, "o público (...) esperava mais alegria, mais amor e mais humor - e menos divagações e floreios intelectuais". Opinião idêntica era a de Ely Azeredo (1967, p.8), que diversas vezes já atacara o Cinema Novo por conta da falta de comunicação entre seus filmes e o público. O crítico apontou para o trunfo do filme ao tratar de um tema universal - devido ao sucesso da canção homônima -, mas apostava na decepção do público, que sairia do cinema sem encontrar o mito que fora buscar. Ainda, alertava que se daria o encontro com o "folclore ipanemense", referente aos "cronistas, poetas, poetinhas e cineastas que habitam o bairro", mas retratados sem "doce balanço". Para José Carlos

\footnotetext{
8 As quatro críticas foram divulgadas pelo Jornal do Brasil sob o título geral de "Garota de Ipanema".
} 
Avellar (1967, p. 8) o problema estava na falta de enredo, preso a uma "historieta" de fotonovela que "não é a imagem fiel de Ipanema, não serve de base para qualquer comentário sobre Ipanema (...)".

Outras críticas apontaram para a falta de precisão nas propostas: afinal, o filme seria Cinema Novo ou um musical hollywoodiano? Para Rubem Biáfora (1968, p. 10), de O Estado de São Paulo, a "melancolia", identificada pelo crítico como um mérito do estilo de Leon Hirszman, ao aparecer "em uma fita do tipo, intenções, finalidades e endereço de Garota de Ipanema é limitação, é "handicap"'.

Ao fim dessa amostragem, percebo que a "melancolia" e os "floreios intelectuais", identificados como traços da estética cinemanovista, se mostram como empecilhos à representação de Ipanema associada à leveza e à descontração. Por fim, Leon não teria, segundo os leitores especializados, se afastado dos pressupostos do Cinema Novo e, por isso, não daria conta de abarcar o universo hedonista exigido pela protagonista de seu filme. Considero oportuno estender essas críticas à justaposição da política e de Ipanema, já que - embora longe de ser um filme político - é exatamente quando ensaia a abordagem do processo de politização de Márcia que a obra adquire as características que foram rechaçadas.

Como apontado inicialmente, o espaço de comunicação do filme preparou os espectadores - incluídos os críticos - para uma ruptura com os pressupostos do Cinema Novo, considerados inadequados para uma história que se passa nas areias de Ipanema. Os profissionais referenciados aqui, no entanto, consideraram, de modo geral, que esses pressupostos não foram totalmente abandonados, o que "contaminaria" a alegria esperada, prejudicando a fruição. Vale, portanto, lançar um olhar mais atento à "República de Ipanema" e ao modo como se fazia política ali, para compreender porque se estabeleceu essa dicotomia em torno do filme.

\section{República de Ipanema, reduto da "esquerda festiva"}

A "República de Ipanema" foi definida por Andrea Queiroz (2011, p. 87) como um esforço de intelectuais - sobretudo, cronistas moradores do bairro - em "construir e (...) divulgar o 'modo de ser carioca' e o ideário de uma 'cidade maravilhosa' principalmente nas décadas de 1960 e 1970". Para esses autores entre eles, Millôr Fernandes, Fernando Sabino, Carlos
Leonam e Vinicius de Moraes - Ipanema representaria o Rio, que por sua vez representaria o Brasil. "Essa relação metonímica fez com que os hábitos e costumes dos moradores daquele ambiente litorâneo da cidade se projetassem como referencial do cidadão carioca como um todo" (QUEIROZ, 2011, p. 95) e, por conseguinte, dos brasileiros também.

Penso ser fundamental enfatizar que a "República" e o bairro de Ipanema não são a mesma coisa, embora se interpenetrem. Estar no bairro - morando ou frequentando - era condição sine qua non para vivenciar a "República", mas não suficiente. Afinal, ela só era alcançável através de códigos e ritos criados e divulgados pelas crônicas dos autores acima indicados. Assim, a vivência do bairro inspirava a constante (re) definição da "República" pelos cronistas e essa, por sua vez, criava modas e modos em Ipanema - num fenômeno que certamente não se restringia a essa parte da urbe, já que, como aponta Beatriz Resende (1995) havia uma relação íntima e plural entre a crônica e o Rio de Janeiro como um todo. Acredito, porém, que a "República de Ipanema" tivesse um apelo mais efetivo, talvez concorrendo apenas com Copacabana. Carlos Leonam (1998, p. 215), por exemplo, afirma que muitos moradores da Zona Norte do Rio, região suburbana, comentavam e elogiavam suas crônicas sobre Ipanema - mas deixa subentendido que a admiração se dava à distância.

Cabe ressaltar que esse imaginário é produzido em um ambiente masculino, heterossexual, machista e de classe média, o que fez com que por vezes alguns valores defendidos pelos cidadãos da "República" se chocassem com suas definições de carioca. A forma como Ruy Castro $(1999$, p. 11) se refere ao bairro é bastante adequada para se compreender esses contrastes: "província de cosmopolitas", Ipanema seria a terra das contradições bem resolvidas. Aberta às novidades e à circularidade sociocultural, mas fechada aos suburbanos. Sexualmente liberada, porém relegando às mulheres o distante papel de musas inspiradoras e respeitando os gays, desde que se mantivessem "discretos". Finalmente, boêmia, mas engajada - não à toa, "esquerda festiva" é uma das expressões criadas por um cronista da "República", que logo seria apropriada pelo país. Vale a pena se aprofundar nessas aparentes contradições, já que, como demonstrado, elas também contaminaram o Cinema Novo quando ele decidiu se aproximar dessa "República", caso de Garota de Ipanema.

Das contradições apresentadas acima, a que mais apelo tem neste artigo é a de "esquerda festiva". 
Segundo a memória de Zuenir Ventura, quem criou a expressão foi o cronista Carlos Leonam, um legítimo "cidadão ipanemense", já citado no artigo por conta de seus comentários sobre a produção de Garota de Ipanema. Em 1963, reagindo a um discurso de San Tiago Dantas, em que este apontava para duas esquerdas - a negativa e a positiva -, Leonam teria constatado, no meio da pista de dança de uma festa, que havia também uma terceira: a festiva. Publicada, a ideia se propagaria e "teria presença assegurada no léxico e no espectro ideológico da política nacional" (VENTURA, 2013, p. 49), sendo utilizada para se referir àqueles que, entre um gole e outro de qualquer bebida alcóolica, discutiam política, defendendo um posicionamento de esquerda, mas sem jamais partir para a prática.

A expressão, embora aplicada nacionalmente, seria muito referida pelos detratores da "República de Ipanema". Além dos motivos apontados acima, tais críticos ainda desqualificavam o humor e a ironia tão presentes no dia a dia da "República", nos textos produzidos por seus cronistas, que demarcavam um modo de se relacionar com a política. Embora sejam reconhecidos meios eficazes de crítica, o humor e a ironia dos "ipanemenses" não serviria, segundo a perspectiva de seus detratores, à denúncia, mas apenas ao lirismo (QUEIROZ, 2011), como se o único objetivo dos textos e imagens fosse fazer rir, mas, não, propiciar a reflexão crítica.

O que desejo fazer aqui é seguir na contramão desse raciocínio, defendendo a possibilidade de coexistência entre a boêmia - que pressupunha uma maneira de usar e se relacionar com a cidade, incluindo nessa fruição o humor e a ironia -, e o posicionamento político. Maria Hermínia Tavares de Almeida e Luiz Weis (1998), ao tratarem da oposição da classe média à ditadura, elencam possibilidades diversas entre as opções extremas de não se envolver de modo algum com política ou aderir à luta armada. Afinal, "ser de oposição incluía assinar manifestos, participar de assembleias e manifestações públicas, dar conferências, escrever artigos, criar músicas, romances, filmes ou peças de teatro" (ALMEIDA; WEIS, 1998, p. 328). Mais adiante, se referindo às universidades, enfatizam que elas funcionavam como meios privilegiados para se chegar "aos teatros (Arena, Opinião, Tuca, Paramount, Casagrande...), aos cinemas (Paissandu, Coral, Trianon...), às associações profissionais (ABI, $\mathrm{OAB}$ ), ou aonde quer que se identificasse uma organização oposicionista" (ALMEIDA; WEIS, 1998, p. 363).
Acredito ser importante ressaltar que algumas atividades citadas não são evidentemente políticas, sendo mais associadas à arte e ao entretenimento - e não apenas à produção dos mesmos, mas também ao seu consumo. Os autores concordam, portanto, que a circulação e vivência em espaços não obviamente "politizados" poderiam ser consideradas válidas como oposição política, funcionando em consonância com outros tipos de engajamento. Levando adiante tais reflexões, é possível conjecturar o exercício da oposição política em festas, bares e praias, por exemplo. Apesar de não fazerem parte dos espaços apontados por Maria Hermínia T. de Almeida e Luiz Weis nas citações acima, acredito que possam também ser tomados como lugares para se opor à ditadura, já que os debates políticos não estavam, a priori, excluídos da socialização efetivada ali.

Os cinemanovistas, reconhecidos por realizar filmes evidentemente políticos, mas também por circular por espaços boêmios por toda a cidade, incluindo Ipanema, poderiam ser abordados a partir dessa dinâmica. Aliás, não seria exagero considerálos como "cidadãos" da "República de Ipanema" e o filme de Leon, ainda que não seja evidentemente sobre seu grupo, poderia ser visto como uma tentativa de retratar seu habitat. Nesse sentido, gostaria de destacar alguns espaços de socialização dos cinemanovistas que servem a essa reflexão, embora somente o segundo estivesse em Ipanema: o cine Paissandu, o botequim Mau-Cheiro e o restaurante Zicartola.

O Paissandu foi criado em 1960, mas foi a partir de 1963, através de uma parceria com a Cinemateca do MAM, que se tornou foco de interesse para jovens cinéfilos que buscavam contato com o cinema de vanguarda europeu e, em menor escala, brasileiro. Segundo Rogério Durst (1996, p. 16), "estética, ideologia e atitude se definiram na seleção dos filmes, que cativaram um público fiel e engajado, nas discussões, antes e depois das sessões, no lobby da sala e, principalmente, nos bares do lado, Oklahoma, e da esquina, Cinerama". Certamente havia - e o autor reconhece - os que iriam ao Paissandu somente por modismo. Porém, muitos outros iam porque gostavam de cinema e de discutir política através dos filmes, dentre eles os cinemanovistas.

A referência aos bares do Paissandu faz lembrar que os botequins também eram importantes espaços de socialização para os cineastas (FIGUEIRÔA, 2004; SIMONARD, 2006). Curiosamente, para o propósito desse artigo, o Mau-Cheiro, bar preferido pelos componentes do Cinema Novo, não ficava 
no Flamengo, perto do Paissandu, mas em Ipanema. Segundo Ruy Castro (1999, p. 251), "o Mau-Cheiro era a vitória do despojamento e da autenticidade de Ipanema sobre a pompa e os preços dos botequins turísticos de Copacabana". Ao longo da década de 1960, se tornaria moda - e não somente por ser o único em Ipanema de frente para o mar, mas também pela presença frequente dos cinemanovistas (QUEIROZ, 2011).

Finalmente, o Zicartola, um exemplo da potência desses ambientes como propiciadores de um complexo circuito de criação artística politizada. $\mathrm{O}$ bar, aberto em 1963 pelo sambista Cartola e sua esposa, D. Zica, era um desdobramento das atividades do CPC da UNE, em que Carlos Lyra, como diretor do Departamento de Música, experimentara e incentivara a aproximação entre a Bossa Nova e o samba de morro (SOUZA, 2007). O restaurante fazia sucesso entre bossanovistas e cinemanovistas que, frequentando esse espaço "de rango e de samba" (LOPES, 2000, p. 59), conviviam com sambistas populares. Foi lá, por exemplo, que Carlos Lyra aprofundou, com Zé Keti, a aproximação com o samba de morro iniciada por ele no CPC (LOPES, 2000), presente, por exemplo, em Quem quiser encontrar o amor, parte da trilha sonora de Couro de gato (Joaquim P. de Andrade, 1962), um dos curtas que compõem Cinco vezes favela, o mesmo filme em que Leon Hirszman estreou. Mesmo considerando apenas essa parceria, já é possível retraçar um itinerário em que a Bossa Nova, nascida na Zona Sul, passa pelo $\mathrm{CPC}$ e se encontra com o samba de morro, frequenta um espaço boêmio do Centro e circula internacionalmente com o Cinema Novo.

De volta a Garota de Ipanema, vale relembrar que a Bossa representada por Leon Hirszman não era essa que convivia com o samba de morro e compunha canções engajadas, mas aquela que se deixava levar pelo balanço da garota na areia e pelo deslizar do barquinho no mar. Mas vale ressaltar que não era a primeira vez que essa vertente lírica da Bossa Nova surgia num filme do movimento. Certamente por conta do teor edênico de suas canções, em diversos filmes cinemanovistas os personagens burgueses, representados como alienados politicamente, são ouvintes da Bossa Nova. Era justamente esse imaginário que o filme pretendia atacar e desconstruir, mas do qual se aproximava em demasia, e perigosamente, ao preferir não opor essa Ipanema hedonista a imagens que remetessem à exclusão social.

No entanto, Leon sabia, como cidadão da "República de Ipanema", que denunciar e filmar as mazelas sociais de modo soturno não era o único modo de fazer política - e que esta poderia ser praticada sem a recusa ao prazer. Não à toa, o diretor inseriu temas políticos no cotidiano de sua protagonista, que, do contrário, poderia ter sido construída "apenas" como uma garota descompromissada. É verdade, por outro lado, que a política entrava em sua vida de maneira tênue, ao modo de uma descoberta ocorrida durante um idílio com um homem mais velho - aliando a política ao prazer de um namoro. Do mesmo modo, permitiu que o Fotógrafo risse de cangaceiros, pais de santo e da Coluna Prestes, enquanto tentava seduzir a garota. Num plano mais específico, o da oposição à ditadura, Leon apostava que a boêmia e o humor não deveriam ser empecilhos - e fez sua garota comentar sobre generais numa conversa de botequim, ensaiar papéis politizados numa sessão de fotos de estúdio, rir enquanto narrava seu tombo ocasionado pela perseguição policial numa passeata.

Esta parece ser a tentativa do diretor de pôr em prática a nova perspectiva que o Cinema Novo ensaiava lançar sobre a sociedade, pensando a política de forma mais descontraída, levemente debochada - mas, ainda assim, com doses muito elevadas de angústia para a maioria dos críticos, que apenas queria ver a garota passar, cheia de graça.

\section{Referências}

ADES, Eduardo; KAUFMAN, Mariana (Org.). Luz em movimento: a fotografia no cinema brasileiro. Rio de Janeiro: Imagem-Tempo produções, 2007.

ALMEIDA, Maria Hermínia Tavares de; WEIS, Luiz. Carro-zero e pau-de-arara: o cotidiano da oposição de classe média ao regime militar. In: NOVAIS, Fernando A. (Org.). SCHWARCZ, Lilia Moritz (coord. do volume 4). História da vida privada no Brasil: contrastes da intimidade contemporânea. São Paulo: Cia das Letras, 1998. p. 319-409.

CALDAS, Waldenyr. A cultura politico-musical brasileira. São Paulo: Musa Editora, 2005.

CAMPO, Mônica Brincalepe. O desafio: filme reflexão no pós1964. In: CAPELATO, Maria Helena et al. (Org.). História e cinema. São Paulo: Alameda, 2011. p. 239-255.

CASTRO, Ruy. Ela é carioca: uma enciclopédia de Ipanema. São Paulo: Cia das Letras, 1999.

DELEUZE, Gilles; GUATTARI, Félix. Mil platôs: capitalismo e esquizofrenia, micropolítica e segmentaridade. Rio de Janeiro: Ed. 34, 1996. Vol. 3.

DURST, Rogério. Geração Paissandu. Rio de Janeiro: Prefeitura, 1996. (Coleção Acervos do Rio).

FIGUEIRÔA, Alexandre. Cinema Novo: a onda do jovem cinema e sua recepção na França. Campinas, SP: Papirus, 2004.

LEONAM, Carlos. Os degraus de Ipanema. Rio de Janeiro: Record, 1998. 
LOPES, Nei. Zé Kéti: o samba sem senhor. Rio de Janeiro: Relume Dumará; Prefeitura, 2000. (Coleção Perfis do Rio).

MALAFAIA, Wolney Vianna. O mal-estar na modernidade: o Cinema Novo diante da modernização autoritária (1964-1984). In: NÓVOA, Jorge; BARROS, José D'Assunção (Org.). Cinemahistória: teoria e representações sociais no cinema. Rio de Janeiro: Apicuri, 2008.

NAPOLITANO, Marcos. A sincope das ideias: a questão da tradição na música popular brasileira. São Paulo: Editora Fundação Perseu Abramo, 2007.

1964: história do regime militar brasileiro. São Paulo, Contexto: 2014.

NEDER, Álvaro. "Parei na contramão": faixas cruzadas na invenção da MPB. Estudos Históricos, Rio de Janeiro, v. 25, n. 49 , p. 50-70, jan.-jun. 2012.

ODIN, Roger. A questão do público: uma abordagem semiopragmática. In: RAMOS, Fernão (Org.). Teoria contemporânea do cinema. São Paulo: Editora Senac São Paulo, 2005. Vol. II. p. 27-45.

Les espaces de communication. Introduction à la sémiopragmatique. Paris: Presses Universitaires de Grenoble, 2011.

QUEIROZ, Andréa Cristina de Barros. Enfim, um escritor com estilo: o jornalista, pasquiniano, ipanemense e sem censura Millôr Fernandes. 2011. Tese (Doutorado em História Social) - Programa de Pós-Graduação em História Social da Universidade Federal do Rio de Janeiro, Rio de Janeiro, 2011.

REIS, Daniel Aarão. Ditadura e sociedade: a reconstrução da memória. In: REIS, Daniel Aarão et al. (Org.). O Golpe e a ditadura militar: 40 anos depois (1964-2004). Bauru, SP: EDUSC, 2004.

RESENDE, Beatriz (Org.). Cronistas do Rio. Rio de Janeiro: José Olympio, 1995.

RIDENTI, Marcelo. Em Busca do povo brasileiro. Rio de Janeiro; São Paulo: Editora Record, 2000.

Cultura e política: os anos 1960 e 1970. In: FERREIRA, Jorge; DELGADO, Lucília de Almeida Neves (Org.). O Brasil Republicano. O tempo da ditadura - regime militar e movimentos sociais em fins do século XX. Rio de Janeiro: Civilização Brasileira, 2003. Vol. 4. p. 133-166.

SALEM, Helena. Leon Hirszman: o navegador de estrelas. Rio de Janeiro: Rocco, 1997.

SIMONARD, Pedro. A geração do Cinema Novo: para uma antropologia do cinema. Rio de Janeiro: Mauad X, 2006.

SOUZA, Miliandre Garcia de. Do teatro militante à música engajada: a experiência do CPC da UNE. São Paulo: Perseu Abramo, 2007.

SUKMAN, Hugo. Histórias paralelas: 50 anos de música brasileira. Rio de Janeiro: Casa da Palavra, 2011.

VENTURA, Zuenir. 1968 - o ano que não terminou. Rio de Janeiro: Objetiva, 2013.

\section{Fontes}

Filmes:

A FALECIDA. Dir. Leon Hirszman. Brasil: Herbert Richers/Meta, DVD, 1965, $90 \mathrm{~min}$.

CINCO VEZES FAVELA. Dir. Leon Hirszman, Joaquim Pedro de Andrade, Miguel Borges, Carlos Diegues e Marcos Farias. Brasil: CPC-UNE/Saga Filmes, DVD, 1962, 92 min.

DEUS E O DIABO NA TERRA DO SOL. Dir. Glauber Rocha. Brasil: Copacabana Filmes, DVD, 1964, 120 min.

GAROTA DE IPANEMA. Dir. Leon Hirszman. Brasil: Saga Filmes, DVD, 1967, 90 min.

JUVENTUDE SEM AMANHÃ. Dir. Elzevir Pereira da Silva e João Cezar Galvão, Brasil: Kratex Produtora Cinematográfica, DVD, 1958, 75 min.

O DESAFIO. Dir. Paulo Cesar Saraceni. Brasil: Mapa Filmes, DVD, 1965, 100 min.

OS CAFAJESTES. Dir. Ruy Guerra. Brasil: Herbert Richers/ Magnus Filmes. DVD, 1962, $93 \mathrm{~min}$.

OS FUZIS. Dir. Ruy Guerra. Brasil: Copacabana Filmes, DVD, 1963, $80 \mathrm{~min}$.

TERRA EM TRANSE. Dir. Glauber Rocha. Brasil: Mapa Filmes, DVD, 1967, 105 min.

VIDAS SECAS. Dir. Nelson Pereira dos Santos. Brasil: Herbert Richers, DVD, 1963, 103 min.

\section{Matérias de jornais e revistas:}

AVELLAR, José Carlos. Garota de Ipanema. Jornal do Brasil, Rio de Janeiro, 31 dez. 1967. Caderno B, p. 8.

AZEREDO, Ely. Garota de Ipanema. Jornal do Brasil, Rio de Janeiro, 31 dez. 1967. Caderno B, p. 8.

BIÁFORA, Rubem. Contradição e Equívoco. O Estado de São Paulo, São Paulo, 19 jan. 1968. p. 10.

GAROTA DE IPANEMA CHEGARÁ EM OUTUBRO. Folha de São Paulo, São Paulo, 15 out. 1967. In: CINEMATECA BRASILEIRA (Org.). Coleção de recortes de jornais e revistas sobre filmes brasileiros, 1958-1973. 44 recortes. Localizador: P.29.

SHATOVSKY, Alberto. Garota de Ipanema. Jornal do Brasil, Rio de Janeiro, 31 dez. 1967. Caderno B, p. 8.

UM AMOR DE GAROTA EM IPANEMA. Revista Visão, s/l, 14 dez. 1967. In: CINEMATECA BRASILEIRA (Org.). Coleção de recortes de jornais e revistas sobre filmes brasileiros, 1958-1973. 44 recortes. Localizador: P.29.

Recebido: 30 de julho de 2016 Aprovado: 05 de novembro de 2016

\section{Autor/Author:}

CARLos EduARDo PinTo DE PinTo dudachacon@gmail.com

- Professor Adjunto do Departamento de História do Instituto de Filosofia e Ciências Humanas da Universidade do Estado do Rio de Janeiro (IFCH/UERJ) e pesquisador do Núcleo de Estudos sobre Biografia, História, Ensino e Subjetividades (NUBHES).

Adjunct Professor of the History Department of the Instituto de Filosofia e Ciências Humanas at the Universidade do Estado do Rio de Janeiro (IFCH/UERJ) and researcher at the Núcleo de Estudo sobre Biografia, História, Ensino e Subjetividades (NUBHES). 